\title{
Vertical Electrical Sounding Investigation of Aquifer Composition and Its Potential to Yield Groundwater in Some Selected Towns in Bida Basin of North Central Nigeria
}

\author{
Ishaku Yakubu Bashir ${ }^{1}$, Mohamad Yusoff Izham $^{1} \&$ Rindam Main ${ }^{1}$ \\ ${ }^{1}$ School of Distance Education, Universiti Sains Malaysia, 11800 USM Penang, Malaysia \\ Correspondence: Ishaku Bashir Yakubu, School of Distance Education, University Sains Malaysia, 11800 USM \\ Penang, Malaysia. Tel: 60-112-620-6878. E-mail: bash20054u@yahoo.ca
}

Received: November 26, 2013 Accepted: December 28, 2013 Online Published: January 21, 2014

doi:10.5539/jgg.v6n1p60

URL: http://dx.doi.org/10.5539/jgg.v6n1p60

\begin{abstract}
Groundwater resource is found beneath the earth crust within the pore spaces or voids between soil particles. Successful groundwater exploration either for domestic, agricultural or industrial uses, pre-drilling information is necessary to determine the depth and yield of groundwater location. Detailed knowledge of the aquifer layer as well as the lithology composition in any successful borehole drilling project is paramount and essential that cannot be ignored. Different geological formations have different groundwater yield potential; therefore, understanding these formations in groundwater exploration becomes imperative. This study adopts Vertical Electrical sounding in sixteen locations group into four stations using geotron G41 earth resistivity meter; with Wenner configuration and maximum electrode spacing at $400 \mathrm{~m}$. The resistivity results were processed using the res1d.exe inversion software. Sounding curves were plotted as apparent resistivity against electrode spacing in Wenner electrode array. Representative resistivity sounding curves types obtained after inversion was used to delineate the aquifer and 1D geoelectric sections. The results show five geoelectric layers in the study area namely: top layer, Clay/sand, Clay, Sand Stone and Sand Clay layer. The groundwater bearing layer varies between 37-70 meters across the study Area.
\end{abstract}

Keywords: vertical electrical sounding, groundwater, aquifer, resistivity and groundwater potential

\section{Introduction}

It has been reported that at least 1.1 billion people across the world lack access to safe, clean drinking water. Nigeria with a population of over 160 million people have invested heavily in borehole Projects throughout the Country to satisfy the fast growing demand for safe water and to improve the socio-economic development of its populace (Eduvie, 2006).

Water is an important liquid necessary for human consumption agriculture and industrial purposes. Most of the world surface water is found to be polluted either from anthropogenic activities by man or nature such as salinity among others factors. These factors have necessitated the purification of surface water before consumption or other uses incurring for cost for exploration and hence giving rise to exploration groundwater as alternative source of water supply.

The world groundwater is estimated to be about $0.06 \%$ of the available water resources out of which $98 \%$ of groundwater is found to be fresh water. Groundwater is found within the pore spaces of soil or rock called the aquifer. The nature of the aquifer is functions of subsurface geological composition that play an important role in determining the circulation of water from the surface (infiltration) to subsurface water through recharge processes. More so; composition of aquifer varies between locations, as each location have a unique geological lithology given rise to variation in groundwater depth among different places. Detail knowledge of the aquifer as well as understanding of aquifer composition is important for optimum groundwater exploration.

Successful groundwater exploration largely depends on the pre- drilling information (survey). Most of the groundwater explorations have failed due to inadequate pre-drilling information. (Gomes, 2006). Different geophysical techniques have been developed to solve exploration problem in petroleum industry. However, as successful as these techniques are in petroleum industry, the economy cost of groundwater explorations are such that the most sophisticated tools are unaffordable in most studies (Schwatz \& Zhang, 2003). 
Electrical resistivity survey has been adopted in groundwater exploration and has help in reviling the geology of the subsurface layer. The resistivity method becomes a versatile geophysical techniques, based on variation of rock and soils resistivity between less than 2 and seismic velocities which usually do not change by more than a factor of 10 (Olasehinde \& Bayewu, 2011). The objective of vertical electrical sounding is to deduce the variation of resistivity's with depth below a given point and correlate it with available geological information to infer groundwater depth while determining layer of promising well or yield.

The electrical resistivity of a surface is a function of the pore-spaces between the particles which allow electric current to flow through it. Therefore, layers with large pore spaces such as sand and sand stones will have a high resistivity value compare to clay layer with a tighter pore space between it particles. The nature of the subsurface resistivity when electric current is injected into it is processed and analysed to give the different lithology and thickness of the layers present. Information about the component of the different layer can infer; present of groundwater in an area. Aquifers are water bearing layers (or formations) that yield water to wells in usable amounts. Typical aquifers are made of sand, gravel or sandstone and clay. These materials have large enough connected pore spaces between grains that water moves freely.

\section{Background of the Study Area}

\subsection{Physiography and Geomorphology of Bida Basin}

Bida basin lies within the Cretaceous-to-Upper Maestrichtian Nupe (Bida or Niger) Basin, Niger trough/Middle Niger Valley South of the River Niger between longitude $5^{\circ} 2^{\prime} \mathrm{E}$ to $6^{\circ} 78^{\prime} \mathrm{E}$ and latitudes $8^{\circ} 2^{\prime} \mathrm{N}$ to $9^{\circ} 46^{\prime} \mathrm{N}$ (Obaje, 2009). This Basin is a sparsely populated region with an estimated population density of about 34 persons per square kilometer, and is mainly dependent on subsistence agriculture and fishery. The dominant topographic feature is the peneplain of the Niger River Trough which stretches from Jebba to Eggan in such a way that the topography is relatively flat-lying near the River Niger, and rises to the crystalline uplands in the south to an elevation of less than $150 \mathrm{~m}$ above mean sea level (msl). Vegetation is of the Guinea Savannah types, with mean annual temperature between $26.5^{\circ} \mathrm{C}$ to $27.8^{\circ} \mathrm{C}$ and mean annual rainfall of $1000 \mathrm{~mm}$ to $1,500 \mathrm{~mm}$ (Adefolalu, 1988; Ayoade, 1974).

\subsection{Geology}

Bida is an approximately NW-SE trending trough filled with mainly Santonia to Maestrichtian sediments of sandstones, siltstones and superficial alluvial deposits (Adeleye, 1976). The lithologies of these formations are weathered literate, sandy clay and clayey sand (Bello \& Makinde, 2007). The southern part of the study area is characterized by formations with secondary permeability's with the following lithology: weathered laterite, sandy clay/clayey sand, fractured basement and fresh basement rocks. Generally the rock units in this region are suggested to be highly characterized by intercalations of clay stone, siltstone, silt, clay and weathered bedrock (Braide, 1990; Akande et al., 2005). These geological materials are usually liable to form aquifer and permeable zones to the bedrocks in both the sedimentary terrain and the crystalline basement complex existing in this area. In areas underlain by crystalline rocks, presence of structures like fractures, fissures, veins, joints and such other structural deformations of the basement complex control the flow of groundwater and also influence the rate of recharge and discharge of the main aquiferous (Akande et al., 2005; Bello \& Makinde, 2007; Idornighie \& Olorunfemi, 1992).

\section{Methodology}

Vertical Electrical Sounding is based on the principle that allows the passage of current into the ground by means of current electrodes and measuring the potential drop between potential electrodes. Current penetrates into the ground with increase in electrodes spacing. In a ground consisting of different lithology with depth, apparent resistivity is measured where the pattern of current flow is influenced by the density, porosity and salinity of the contained fluid in the ground (Mohammed et al., 2007).

Sixteen (16) Vertical Electrical Sounding (VES) stations using Wenner electrode array were established along roads and some open space in the study area. The resistivity measurements were made by using Geotron earth resistivity meter- model G41.The equipment is a fully automated resistivity meter for DC electrical surveys. Measurements were made by injecting current into the ground through two current electrodes $\mathrm{P}_{1}$ and $\mathrm{P}_{2}$ and measuring the resulting voltage difference at the potential electrodes $C_{1}$ and $C_{2}$ respectively (Figure 1 ). The current and potential electrode separation is spatially increased simultaneously about the mid-point (O) from 0.2 $\mathrm{m}$ to $100 \mathrm{~m}$ until the length of the array (L) is exhausted and the potential difference is measured. The measured data were processed and interpreted automatically using the res1d.exe inversion software. This software is used to obtain true resistivity and depth from the apparent resistivity data obtained at each VES location. Sounding 
curves were plotted as apparent resistivity against electrode spacing in Wenner electrode array. Due to the lithological variation of the study site, near-surface inhomogeneities and topographical variation, which create 2D effects; a 2D modelling was developed using the estimated resistivities and thickness, and its equivalent 2D effect shown across VES stations.

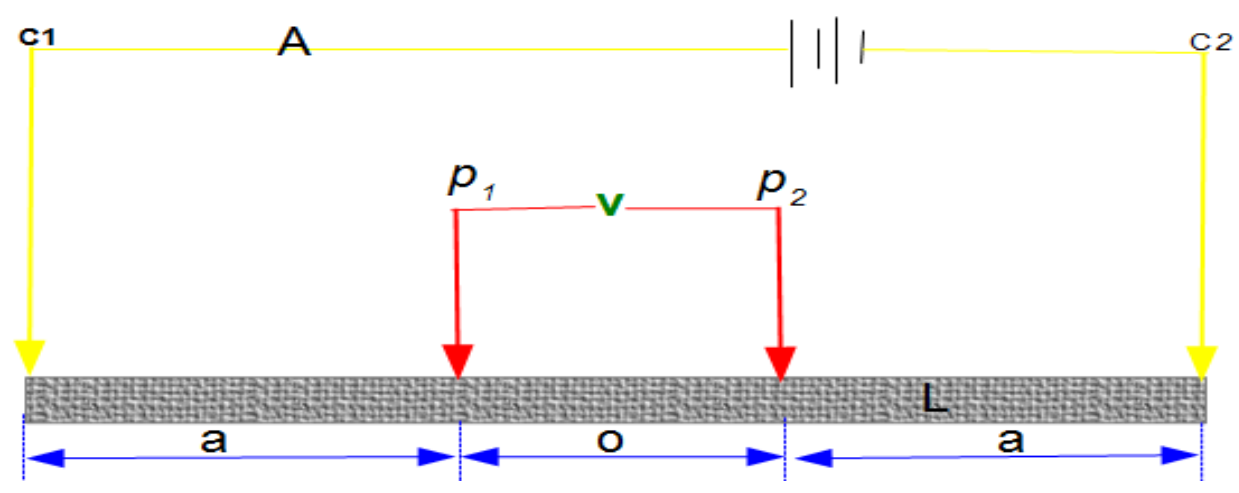

Figure 1. Electrical configuration for the data collection (Wenner)

Wenner configuration protocol with a maximum electrode spacing of 100 meter was used throughout the study because of its advantage of depth penetration over other electrical configuration protocol (El-Difrawy et al., 2006; Giao, 2003). Result obtained were interpreted and inverted using res1d.xe software with initial starting models. Based on inversion results; the different curve types were identify using three layer model curves; A, H, K and Q. The electrical profiling was drawn from the results obtained and a borehole logs within the study area was used as justification for the profiling lithology.

\section{Result}

VES model resistivity values and their Corresponding thicknesses are shown in Table 1. The top layer shows a high resistivity values ranging between $193.85-2637.37 \Omega / \mathrm{m}$ with a thickness of between $0.05-2.17 \mathrm{~m}$. The clay sand layer has resistivity between 35.01-1092.29 $\Omega / \mathrm{m}$ and a thickness of 0.7 to $9.09 \mathrm{~m}$. The third layer corresponds to sand stone layer with resistivity ranging from $29.96-1087.02 \Omega / \mathrm{m}$ and a thickness of between $3.99-23.02 \mathrm{~m}$. The fourth layer has resistivity between $34.22-829.08 \Omega / \mathrm{m}$ and a thickness of $8.45-62.44 \mathrm{~m}$ respectively. Frequency distribution of the curve types (Figure2) show a predominant of QHA curves while KHA curves is the least occurrence curve in the study area.

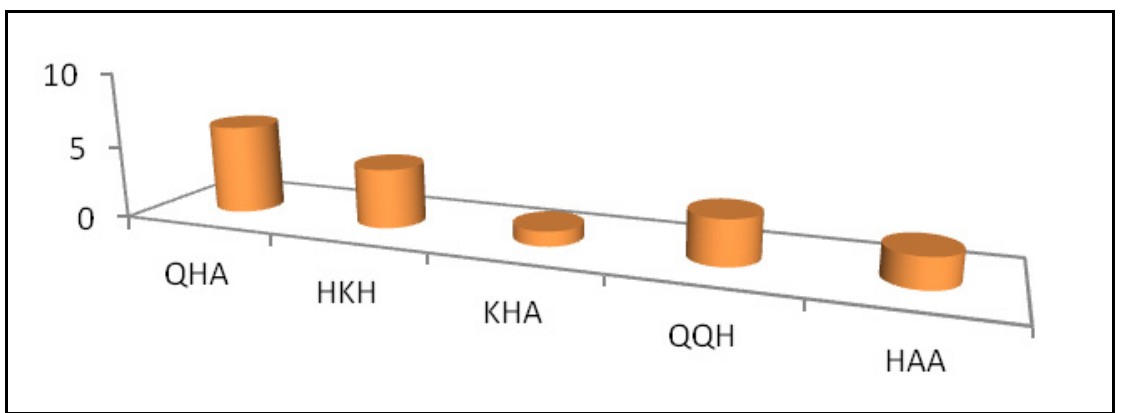

Figure 2. Curves types distribution in the study area

\subsection{Discussion of Results}

The resistivity survey results was analysed and interpreted to enable the delineation of the geoelectric sections of the study area. From the resistivity survey five different layers were delineated at each VES points. The first layer has a resistivity between $193.87 \Omega / \mathrm{m}-2637.372 \Omega / \mathrm{m}$ at VES 14 and 10 and has a thickness of $0.05 \mathrm{~m}$ to $2.17 \mathrm{~m}$ at VES 4 and 14. The second layer has resistivity between $35.01 \Omega / \mathrm{m}-1092.29 \Omega / \mathrm{m}$ at VES 14 and 4 ; with a thickness of $0.7 \mathrm{~m}-9.09 \mathrm{~m}$. The third layer show resistivity value of $33.18 \Omega / \mathrm{m}-1087.02 \Omega / \mathrm{m}$ at VES 9 and 16; while the thickness is between $3.99 \mathrm{~m}-23.02 \mathrm{~m}$ at VES 13 and 14 respectively. The fourth layer has a 
resisitivity values of $34.22 \Omega / \mathrm{m}-602 \Omega / \mathrm{m}$ at VES 3 and 13 ; while the thickness of the fourth layer is between $13.52 \mathrm{~m}-62.44 \mathrm{~m}$ at VES point 11 and 7 . The under laying layer show a sharp increse in reisistivity indicating that it has different geoelectrical properties with the preceeding layers and hence can not be estimated.

Table 1. Summary of VES model resistivity values and their corresponding thicknesses

\begin{tabular}{|c|c|c|c|c|c|c|c|c|c|c|c|}
\hline \multirow{2}{*}{$\begin{array}{l}\text { VES } \\
\text { Point }\end{array}$} & \multicolumn{2}{|c|}{ Layer 1} & \multicolumn{2}{|c|}{ Layer 2} & \multicolumn{2}{|c|}{ Layer 3} & \multicolumn{2}{|c|}{ Layer 4} & \multicolumn{2}{|c|}{ Layer 5} & \multirow{2}{*}{$\begin{array}{l}\text { Curve } \\
\text { Type }\end{array}$} \\
\hline & $\begin{array}{c}\text { Resistivity } \\
(\Omega \mathrm{m})\end{array}$ & $\begin{array}{c}\text { Thickness } \\
\text { (m) }\end{array}$ & $\begin{array}{c}\text { Resistivity } \\
(\Omega \mathrm{m})\end{array}$ & $\begin{array}{c}\text { Thickness } \\
\text { (m) }\end{array}$ & $\begin{array}{c}\text { Resistivity } \\
(\Omega \mathrm{m})\end{array}$ & $\begin{array}{c}\text { Thickness } \\
\text { (m) }\end{array}$ & $\begin{array}{c}\text { Resistivity } \\
(\Omega \mathrm{m})\end{array}$ & $\begin{array}{c}\text { Thickness } \\
\text { (m) }\end{array}$ & $\begin{array}{c}\text { Resistivity } \\
(\Omega \mathrm{m})\end{array}$ & $\begin{array}{c}\text { Thickness } \\
\text { (m) }\end{array}$ & \\
\hline VES1 & 1091.23 & 1.00 & 388.31 & 9.09 & 165.31 & 11.78 & 829.09 & 22.03 & 1138.25 & - & QHA \\
\hline VES2 & 1832.38 & 0.50 & 194.08 & 1.14 & 564.32 & 12.17 & 209.91 & 16.72 & 1251.67 & - & $\mathrm{HKH}$ \\
\hline VES3 & 1140.01 & 0.08 & 168.07 & 1.90 & 65.10 & 11.24 & 34.22 & 37.23 & 313.64 & - & КHA \\
\hline VES4 & 1157.62 & 0.05 & 1092.29 & 2.34 & 202.54 & 14.79 & 565.58 & 8.45 & 2450.08 & - & QHA \\
\hline VES5 & 1731.93 & 0.36 & 766.421 & 2.41 & 101.66 & 17.56 & 408.19 & 28.35 & 12464.45 & - & QHA \\
\hline VES6 & 1369.39 & 0.40 & 910.21 & 1.44 & 280.63 & 13.66 & 75.92 & 54.73 & 1410.78 & - & QQH \\
\hline VES7 & 1169.16 & 0.81 & 225.84 & 2.25 & 868.44 & 4.18 & 94.29 & 62.44 & 1210.48 & - & $\mathrm{HKH}$ \\
\hline VES8 & 1369.04 & 1.00 & 909.92 & 2.44 & 910.21 & 13.66 & 75.91 & 54.73 & 2533.73 & - & $\mathrm{HKH}$ \\
\hline VES 9 & 1146.92 & 1.13 & 590.70 & 8.59 & 1087.02 & 11.862 & 498.76 & 27.56 & 9658.00 & - & $\mathrm{HKH}$ \\
\hline VES10 & 2637.37 & 0.53 & 683.86 & 0.70 & 646.85 & 9.84 & 137.35 & 19.17 & 14656.53 & - & QQH \\
\hline VES11 & 1131.32 & 0.54 & 403.90 & 2.66 & 54.28 & 10.76 & 339.81 & 13.52 & 1373.67 & - & QHA \\
\hline VES12 & 1473.78 & 0.54 & 623.44 & 2.87 & 146.41 & 7.71 & 35.54 & 16.77 & 1679.32 & - & QQH \\
\hline VES13 & 1212.99 & 2.12 & 327.07 & 2.107 & 347.84 & 3.99 & 602.58 & 20.736 & 872.00 & - & HAA \\
\hline VES14 & 193.87 & 2.17 & 35.01 & 6.49 & 29.96 & 23.02 & 157.31 & 13.30 & 536.97 & - & QHA \\
\hline VES15 & 1308.77 & 1.56 & 284.03 & 4.16 & 502.51 & 22.17 & 543.55 & 20.30 & 3308.00 & - & HAA \\
\hline VES16 & 1308.39 & 0.52 & 126.50 & 3.751 & 33.18 & 8.69 & 334.34 & 16.953 & 1286.27 & - & QHA \\
\hline
\end{tabular}

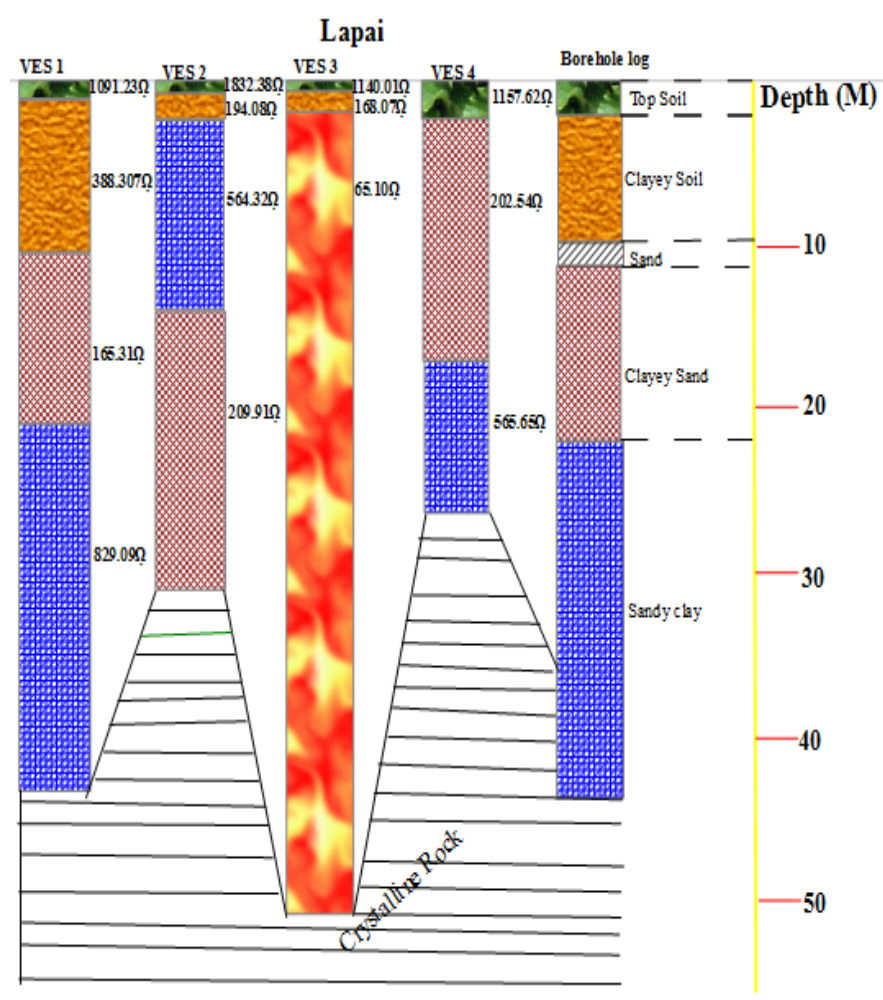

Figure 3. Geoelectric section and BHL of Lapai 


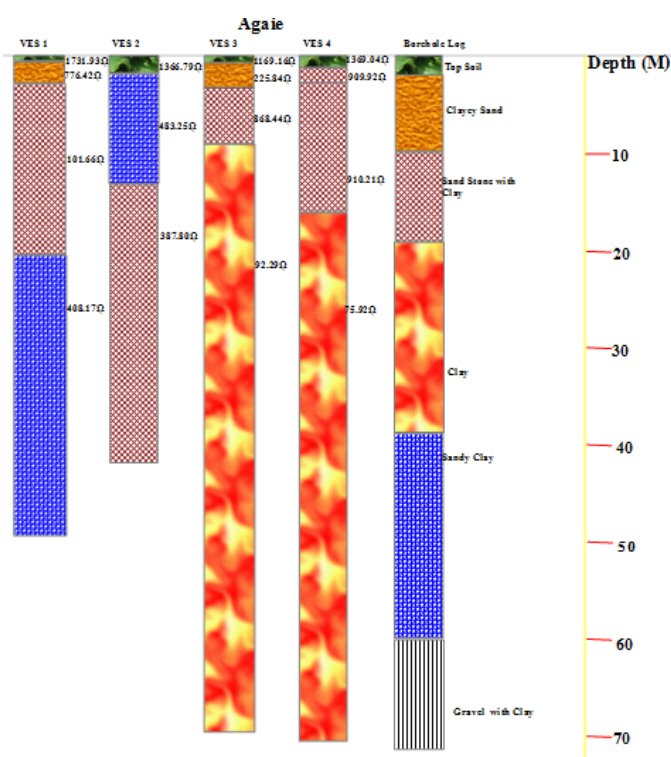

Figure 4. Geoelectric section and BHL of Agaie

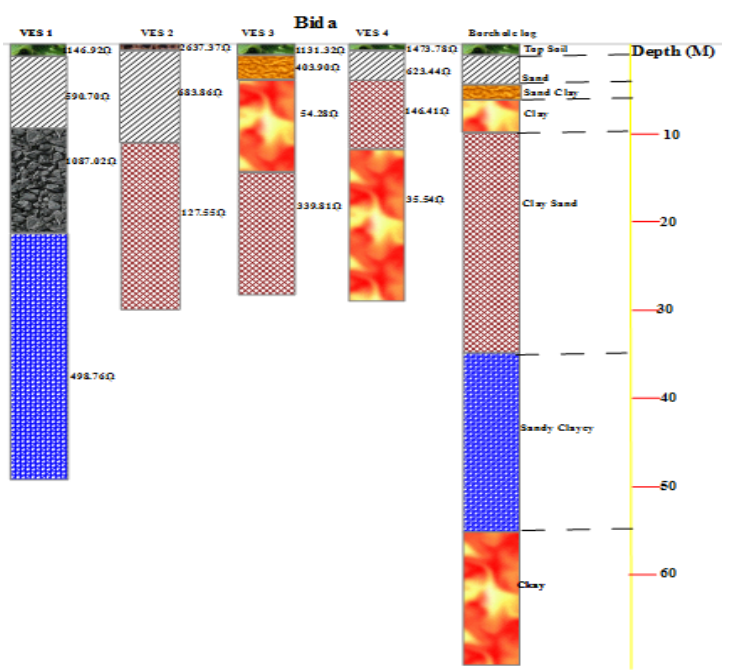

Figure 5. Geoelectric section and BHL of Bida

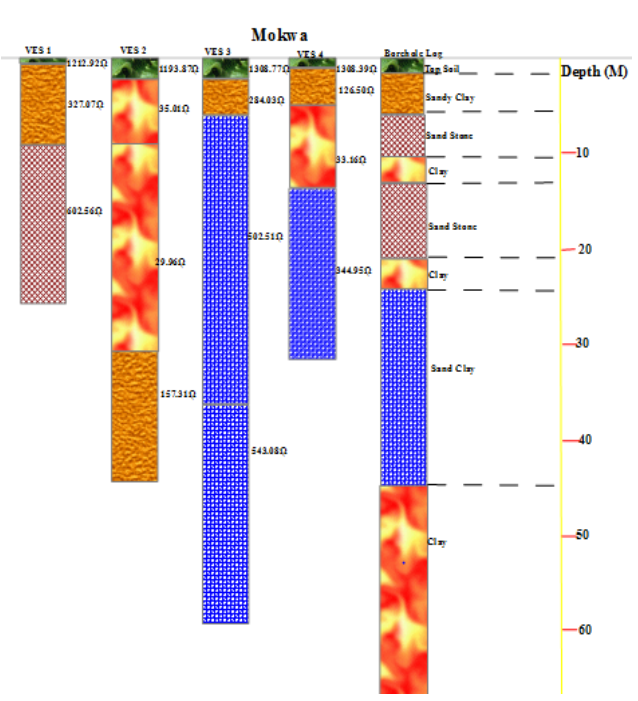

Figure 6. Geoelectric section and BHL of Mokwa 
The occurrence of uncertainty in 1D interpretations, such that different layer model yield nearly the same response to electric current during resistivity survey is common. These ambiguities can be treated when drawing the geoelectric section by margin such layers with similar or close resistivity value as the same guided by the principle of equivalent and suppression (Yadav \& Singh, 2007; Sharma \& Kaikkonen, 1999; Nath et al., 2000). Therefore, resistivity contrast of few meters was suppressed as same clay layer in Figure 6 (VES 2) since the difference in their resistivity is almost the same.

\subsection{Components of the Aquifer and Groundwater Potentials}

From the resistivity survey results and available borehole logging from the study area show a lithology of three (3) to four (4) layers present. Each of these layers having a unique characteristics constituent of the layer. As mentioned earlier from the 1D section, the first layer is the top soil, the second layer is the Sand Clay, and the third layer is Sand Stone; fourth layer as Clay sand while the fifth layer is clay.

The superficial geoelectric layer (top layer) is characterized by relatively high electrical resistivity values (1140.01-1703.76 ohm-m) and thin depth of $(0.08 \mathrm{~m}-2.38 \mathrm{~m})$. It constitutes mainly of littered weathered material, sand, and some bolder rocks particles with the maximum depth occurring at the south east of the study area (Figure 7).

The second layer is made up of sand clay. The layer serve as a fielder bed through which pollutant in infiltrated water is prevented from reaching the confined aquifer or water table. The thin thickness of the sand clay layer in Figure 4 makes it liable to pollution while the layer is thicker at VES 4 Figure 7 hence less vulnerable to pollutions from the surface.

The groundwater bearing zones in the area is mostly located between the clay and the sand clay layer corresponding to fourth layer. The responsible factor for this is attributed to porosity and permeability of aquifer contents. Clay has high porosity; hence, half of its volume store water. The void between clay particles is microscopically small with large surface area favour slow movement and retention of water. Clays do not make good aquifers compared to sand clay with lower porosity for free flow of water as sands clays have more interconnected pores (Singhal \& Gupta, 2010).

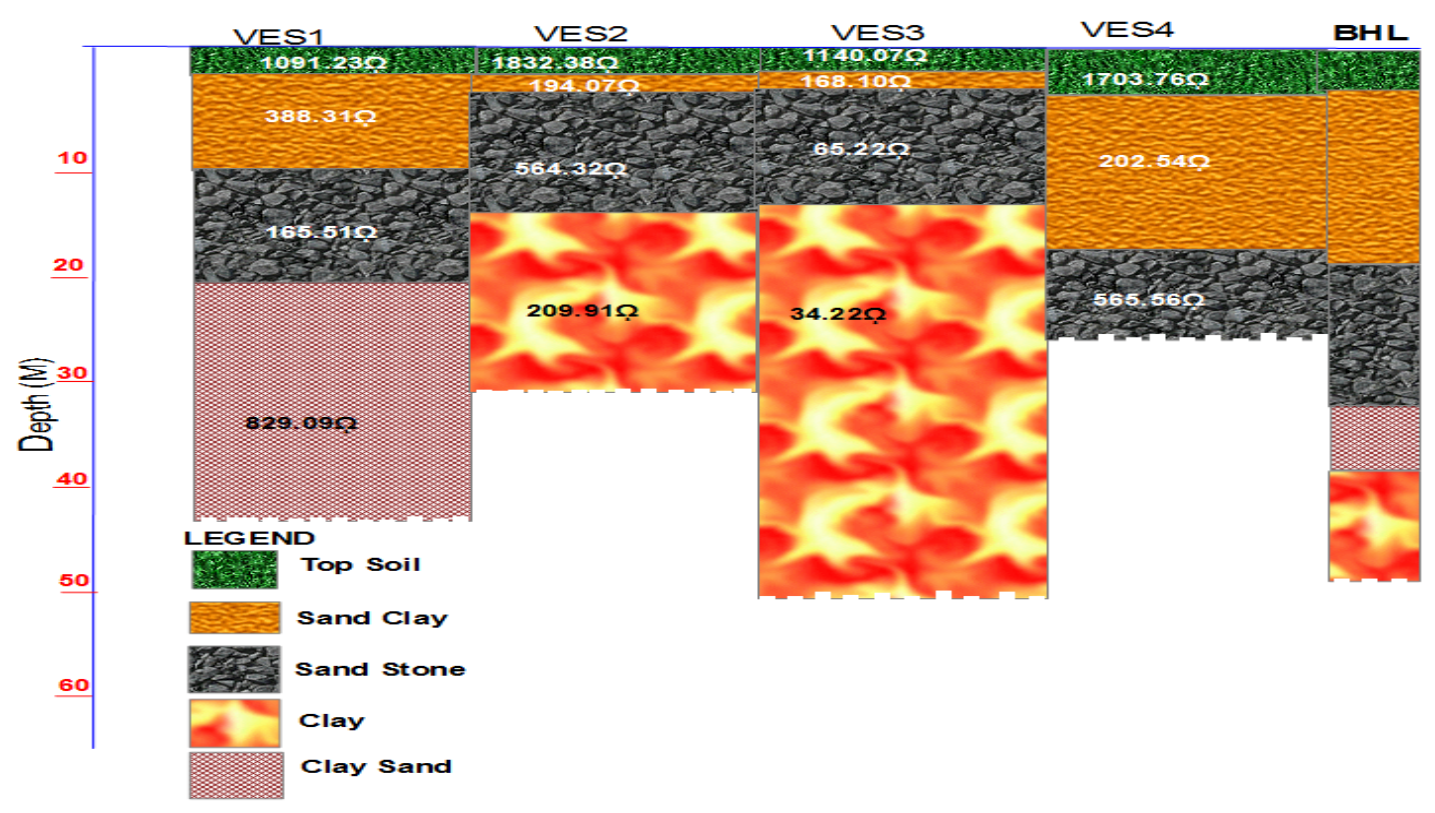

Figure 7. 2D geoelectric section of Lapai

\subsection{Profiling of the Study Area}

The major aquifer (water bearing unit) of the study area is mainly weathered basement due to the good porosity and permeability characteristics of the material medium depending on the amount of clay material present. However, in Figure 5 (Lapai); the available borehole lithology indicates that the northern part is made up of basement formation similar to Figures 2, 3, and 4. The south Western part is made of sedimentary formation. 
This is confirmed by the resistivity results; where the composition of the lithology differs between VES 1, 2, 3 and 4 where 4 appeared with a distinct layer indicating that VES 4 is of sedimentary formation. The groundwater yield potential is higher in VES 1, 2 and 3 since sand clay (VES 1) having a large pore for storage of water within it pore spaces while VES 2, and 3 have a fair water yield potential. VES 4 have a poor yield capacity since the constituents is made of sand stone allowing for poor groundwater storage. The sand stone zone is the aquiclude layer while clay and clay sand is the aquifer layer (Chilton \& Foster, 1995; Idris-Nda \& Nwosu, 2006).

The groundwater yield in basement complex terrain is generally low for clay bearing/low permeability weathered layer aquifer and high for weathered and fractured aquifer with enhanced permeability through secondary porosity (Olorunfemi et al., 2005; Olorunfemi \& Fasuyi, 1993).

For a sustainable groundwater exploration, the depth of drilling can be terminated at 36-70 meters. This is capable of yielding the desired groundwater. In the study area based on the results and available boreholes lithology data, VES 1and 3 (Figure 7), VES 1, 3 and 4 (Figure 8), VES 1 and 3 (Figure 9) and VES 3 (Figure 10) are the promising wells in the study area.

The existence of fault within the study area to a larger extend determined the depth of groundwater in the area (Adiat et al., 2012). In Lapai (Figure 5) the groundwater depth (i.e. aquifer) is between 34-40 meters in basement area and 40-50 m in the sedimentary complex. Agaie and Mokwa (Figures 2 and 4) have a groundwater depth between 60 to 75 meters respective with clay sand and clay as the aquifer and sand stone as the aquiclude. Bida (Figure 3) have a groundwater depth between 40 to 50 meters.

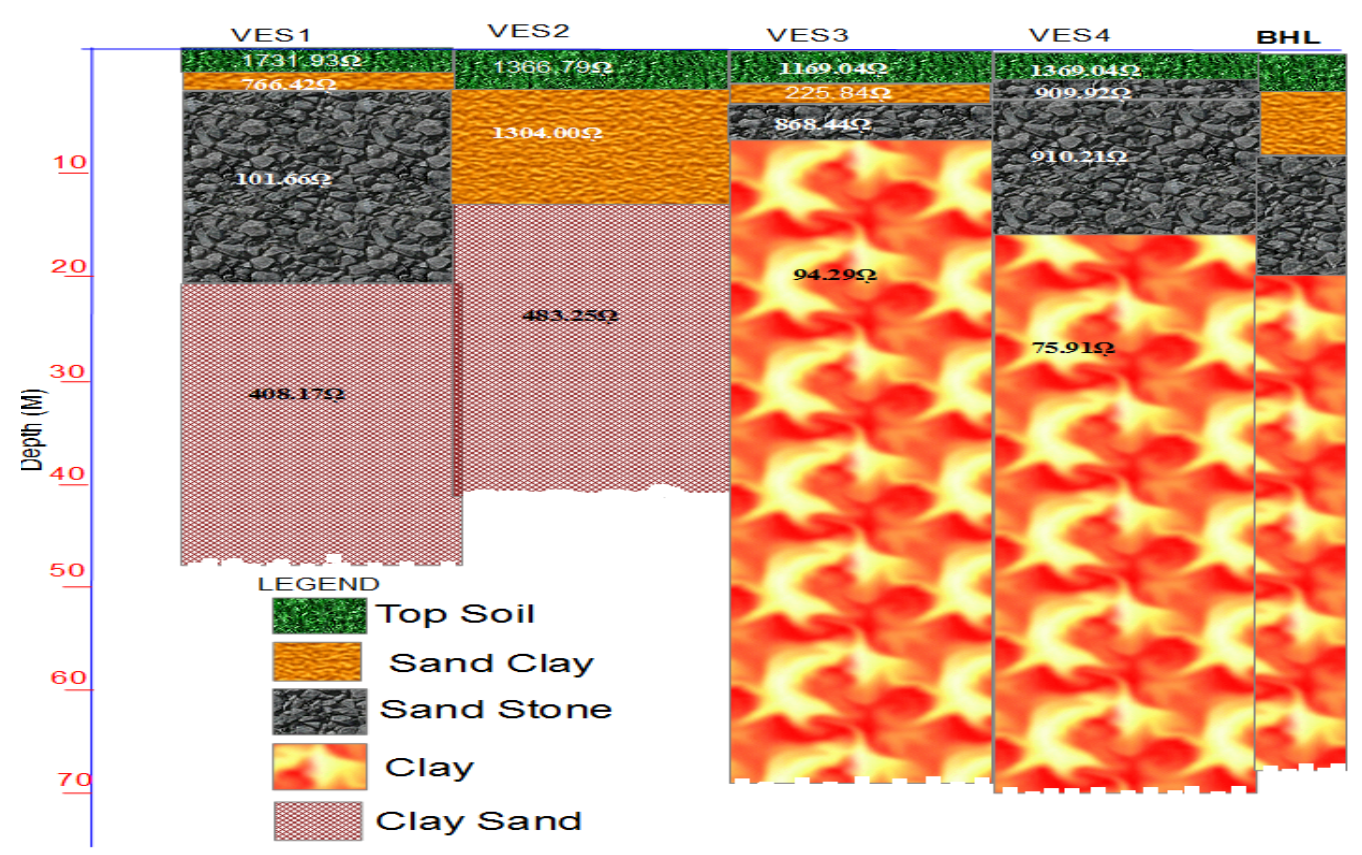

Figure 8. 2D geoelectric profile of Agaie 


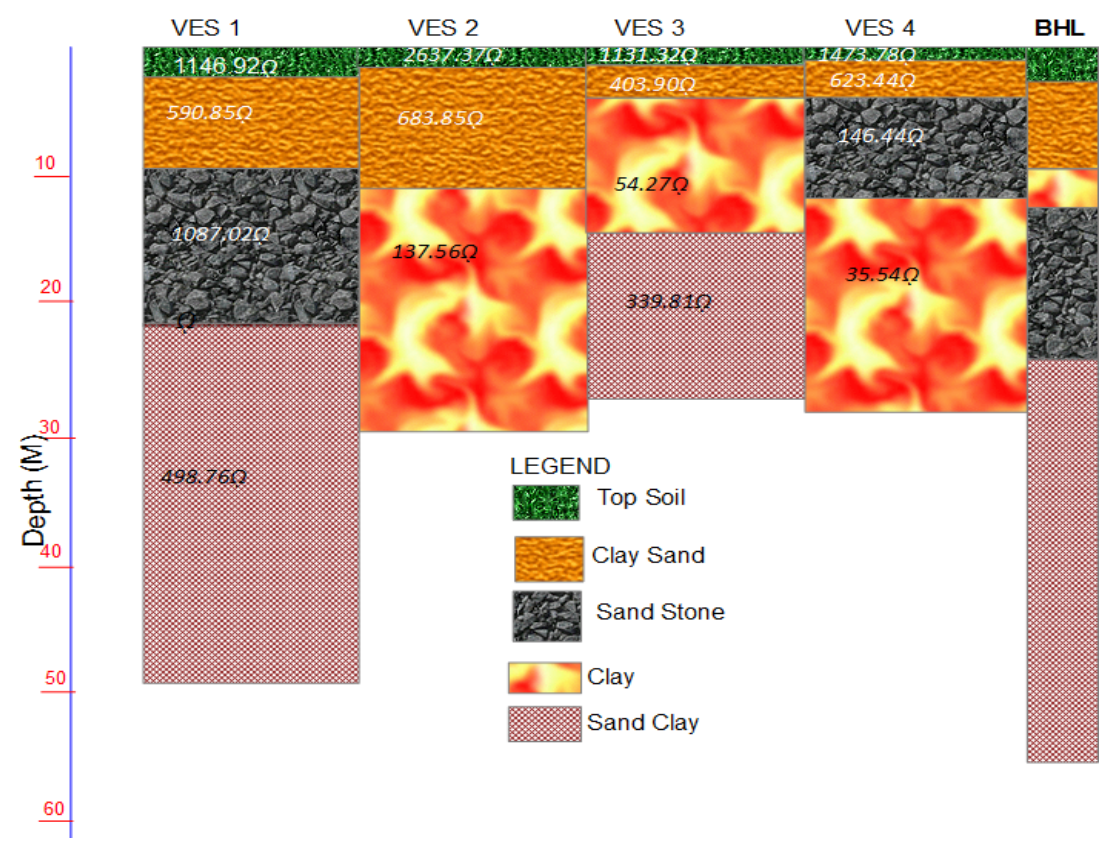

Figure 9. 2D geoelectric profile of Bida

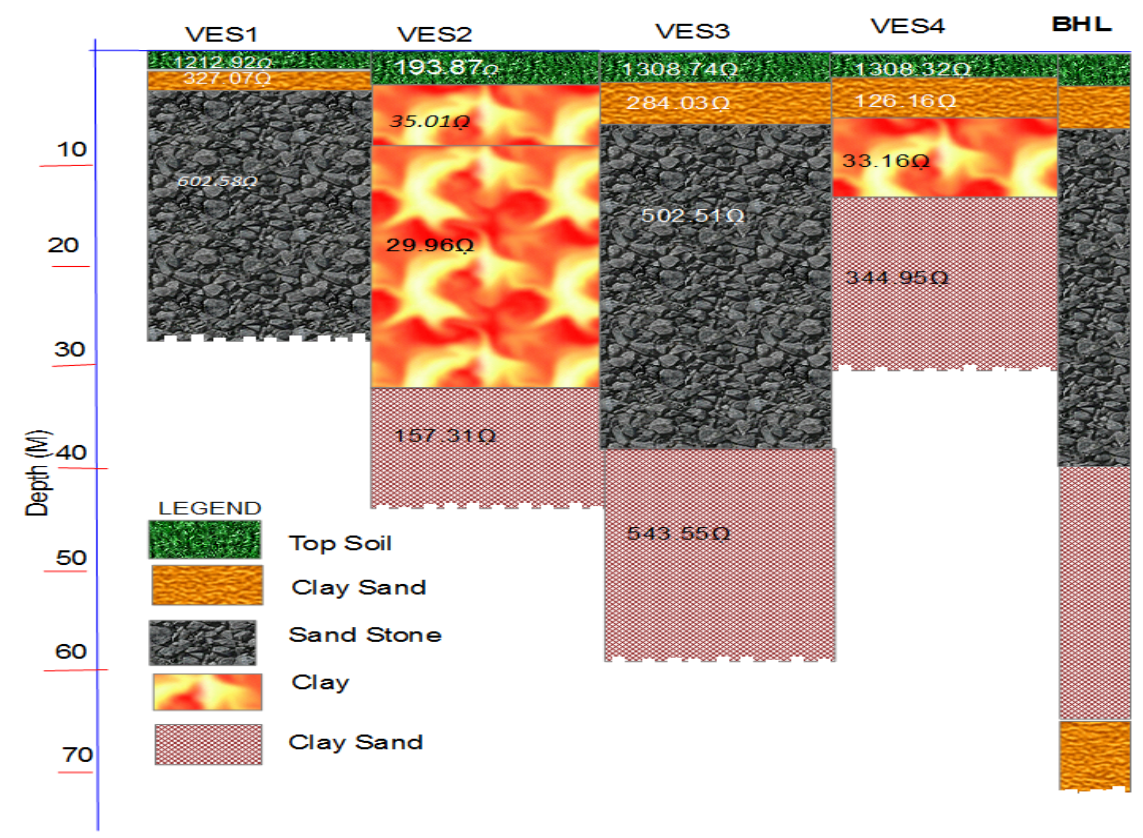

Figure 10. 2D geoelectric profile for Mokwa

\section{Conclusion}

A vertical electrical sounding method has been applied and the results were able to delineate different geoelctric sections which were correlated with available borehole logs; to determine their corresponding geological formations. The promising well were from the resistivity survey were mapped based on the nature and properties that constitutes the aquifer layer and the overburden material and thickness.

\section{References}

Adefolalu, D. (1988). Precipitation trends, evapotranspiration and the ecological zones of Nigeria. Theoretical and applied climatology, 39, 81-89. http://dx.doi.org/10.1007/BF00866392 
Adeleye, D. R. (1976). The geology of the middle Niger Basin. Geology of Nigeria, Elizabethan Publishing Company Limited, Lagos, 283-287.

Adiat, K. A. N., Nawawi, M. N. M., \& Abdullah, K. (2012). Application of multi-criteria decision analysis to geoelectric and geologic parameter for prediction of groundwater resources potential and aquifer evaluation. Pure Appl. Geophys., 170, 453-471. http://dx.doi.org/10.1007/s00024-012-0501-9

Akande, S., Ojo, O., Erdtmann, B., \& Hetenyi, M. (2005). Paleoenvironments, organic petrology and Rock-Eval studies on source rock facies of the Lower Maastrichtian Patti Formation, southern Bida Basin, Nigeria. Journal of African Earth Sciences, 41, 394-406. http://dx.doi.org/10.1016/j.jafrearsci.2005.07.006

Ayoade, J. (1974). A statistical analysis of rainfall over Nigeria. Journal of Tropical Geography, 39, 11-23.

Bello, A. A., \& Makinde, V. (2007). Delineation of the aquifer in the South-Western part of the Nupe Basin, Kwara State, Nigeria. J. Am. Sci., 3, 36-44.

Braide, S. P. (1990). Petroleum geology of the southern Bida basin, Nigeria. AAPG Bulletin (American Association of Petroleum Geologists);(USA), 74(CONF-900605--).

Chilton, P. J., \& Foster, S. (1995). Hydrogeological characterisation and water-supply potential of basement aquifers in tropical Africa. Hydrogeology Journal, 3, 36-49. http://dx.doi.org/10.1007/s100400050061

Eduvie, M. O. (2006). Borehole failures and groundwater development in Nigeria. Water Africa Exhibition, Lagos, Nigeria.

El-Difrawy, M., El-Behiry, M., Refai, E., \& Morsey, E. (2006). Digital Linear Filtering Method to Transform Schlumberger to Wenner Electric Resistivity Data. Earth Sciences, 17, 69-82.

Giao, P. H. (2003, September). A comparative study of different electric imaging configurations in investigation of a fresh-saline groundwater interface. In 9th EAGE/EEGS Meeting.

Gomes, N. (2006). Access to Water, Pastoral Resource Management and Pastoralists' Livelihoods; Lessons Learned From Water Development in Selected Areas of Eastern Africa (Kenya, Ethiopia, Somalia). In NATIONS, F. A. A. O. O. T. U. (ed.).

Idornighie, A., \& Olorunfemi, M. (1992). A Geoelectric Mapping of the Basement Structures of the Southcentral part of the Bida Basin and its Hydro Geological Implications. Journal of Mining and Geology, 28, 93-103.

Idris-Nda, A., \& Nwosu, J. E. (2006). Groundwater Development Programme in Parts of the Northern Sector of the Bida Basin. In Book of readings: 2nd annual School of Science and Science Education Conference, Federal University of Technology, Minna: date, 19th-22nd November, 2006: theme, challenges in science and technological advancement and economic reforms (p. 129).

Mohammed, I. N., Aboh, H. O., \& Emenike, E. A. (2007). A regional geoelectric investigation for groundwater exploration in Minna area, north west Nigeria. Science World Journal, 2(4).

Nath, S. K., Shahid, S., \& Dewangan, P. (2000). SEISRES-a Visual $\mathrm{C}<\sup >++</$ sup $>$ program for the sequential inversion of seismic refraction and geoelectric data. Computers \& Geosciences, 26(2), 177-200. http://dx.doi.org/10.1016/S0098-3004(99)00086-2

Obaje, N. G. (2009). The Mid-Niger (Bida) Basin. In Geology and Mineral Resources of Nigeria (pp. 91-101). Berlin Heidelberg: Springer.

Olasehinde, P., \& Bayewu, O. (2011). Evaluation of electrical resistivity anisotropy in geological mapping: A case study of Odo Ara, West Central Nigeria. African Journal of Environmental Science and Technology, 5, 553-566.

Olorunfemi, M., \& Fasuyi, S. (1993). Aquifer types and the geoelectric/hydrogeologic characteristics of part of the central basement terrain of Nigeria (Niger State). Journal of African Earth Sciences (and the Middle East), 16, 309-317. http://dx.doi.org/10.1016/0899-5362(93)90051-Q

Olorunfemi, M., Fatoba, J., \& Ademilua, L. (2005). Integrated VLF-Electromagnetic and electrical resistivity survey for groundwater in a crystalline basement complex terrain of southwest Nigeria. Global Journal of Geological Sciences, 3, 71-80. http://dx.doi.org/10.4314/gjgs.v3i1.18714

Schwartz, F. W., \& Zhang, H. (2003). Fundamentals of ground water.

Sharma, S. P., \& Kaikkonen, P. (1999). Appraisal of equivalence and suppression problems in 1D EM and DC measurements using global optimization and joint inversion. Geophysical prospecting, 47(2), 219-249. http://dx.doi.org/10.1046/j.1365-2478.1999.00121.x 
Singhal, B. B. S., \& Gupta, R. P. (2010). Applied hydrogeology of fractured rocks. Springer. http://dx.doi.org/10.1007/978-90-481-8799-7

Yadav, G. S., \& Singh, S. K. (2007). Integrated resistivity surveys for delineation of fractures for ground water exploration in hard rock areas. Journal of applied geophysics, 62(3), 301-312. http://dx.doi.org/10.1016/j.jappgeo.2007.01.003

\section{Copyrights}

Copyright for this article is retained by the author(s), with first publication rights granted to the journal.

This is an open-access article distributed under the terms and conditions of the Creative Commons Attribution license (http://creativecommons.org/licenses/by/3.0/). 